\title{
Efficient generation of GGTA1-deficient pigs by electroporation of the CRISPR/Cas9 system into in vitro-fertilized zygotes
}

\author{
Fuminori Tanihara ${ }^{1}$, Maki Hirata ${ }^{1 *}$ (D), Nhien Thi Nguyen ${ }^{1}$, Osamu Sawamoto ${ }^{2}$, Takeshi Kikuchi', Masako Doi ${ }^{2}$ and
} Takeshige Otoi ${ }^{1}$

\begin{abstract}
Background: Xenoantigens are a major source of concern with regard to the success of interspecific xenografts. GGTA1 encodes a1,3-galactosyltransferase, which is essential for the biosynthesis of galactosyl-alpha 1,3-galactose, the major xenoantigen causing hyperacute rejection. GGTA1-modified pigs, therefore, are promising donors for pigto-human xenotransplantation. In this study, we developed a method for the introduction of the CRISPR/Cas9 system into in vitro-fertilized porcine zygotes via electroporation to generate GGTA1-modified pigs.

Results: We designed five guide RNAs (gRNAs) targeting distinct sites in GGTA1. After the introduction of the Cas9 protein with each gRNA via electroporation, the gene editing efficiency in blastocysts developed from zygotes was evaluated. The gRNA with the highest gene editing efficiency was used to generate GGTA1-edited pigs. Six piglets were delivered from two recipient gilts after the transfer of electroporated zygotes with the Cas9/gRNA complex. Deep sequencing analysis revealed that five out of six piglets carried a biallelic mutation in the targeted region of GGTA1, with no off-target events. Furthermore, staining with isolectin B4 confirmed deficient GGTA1 function in GGTA1 biallelic mutant piglets.

Conclusions: We established GGTA1-modified pigs with high efficiency by introducing a CRISPR/Cas9 system into zygotes via electroporation. Multiple gene modifications, including knock-ins of human genes, in porcine zygotes via electroporation may further improve the application of the technique in pig-to-human xenotransplantation.
\end{abstract}

Keywords: GGTA1, CRISPR/Cas9, Electroporation, In vitro fertilization, Pig

\section{Background}

Gene-modified pigs are ideal experimental animal models of human disease and donors for pig-to-human xenotransplantation [1-3]. As the life expectancy of humans increases, the incidences of chronic diseases and end-stage organ failure as well as demand for organ transplantation increase [2, 3]. In the context of a shortage in human organs for transplantation, pigs have

\footnotetext{
* Correspondence: mhirata@tokushima-u.ac.jp

'Laboratory of Animal Reproduction, Faculty of Bioscience and Bioindustry, Tokushima University, 2272-1 Ishii, Myozai-gun, Tokushima 779-3233, Japan Full list of author information is available at the end of the article
}

gained importance as an alternative source. However, xenoantigens are a major source of concern for interspecific xenografts. Antibody-xenoantigen complexes lead to complement activation and immediate hyperacute rejection [4]. The major xenoantigen expressed in porcine tissues is the galactosyl-alpha 1,3-galactose (Gal $\alpha(1$, 3) Gal) epitope, which is expressed on the surface of porcine endothelial cells and causes hyperacute rejection [3, 5].

a1,3-Galactosyltransferase, encoded by the glycoprotein galactosyltransferase alpha 1,3 (GGTA1), is essential for the biosynthesis of $\operatorname{Gal\alpha }(1,3) \mathrm{Gal}$ [5]. The

C C The Author(s). 2020 Open Access This article is licensed under a Creative Commons Attribution 4.0 International License, which permits use, sharing, adaptation, distribution and reproduction in any medium or format, as long as you give appropriate credit to the original author(s) and the source, provide a link to the Creative Commons licence, and indicate if changes were made. The images or other third party material in this article are included in the article's Creative Commons licence, unless indicated otherwise in a credit line to the material. If material is not included in the article's Creative Commons licence and your intended use is not permitted by statutory regulation or exceeds the permitted use, you will need to obtain permission directly from the copyright holder. To view a copy of this licence, visit http://creativecommons.org/licenses/by/4.0/ The Creative Commons Public Domain Dedication waiver (http://creativecommons.org/publicdomain/zero/1.0/) applies to the data made available in this article, unless otherwise stated in a credit line to the data. 
establishment of GGTA1-deficient pigs lacking the functional Gal $\alpha(1,3)$ Gal epitope is a key step in controlling xenograft rejection. Since its establishment, somatic cell nuclear transfer (SCNT) has been the primary method for the generation of genetically modified pigs [6, 7]. Recently, gene editors such as zinc finger nuclease [8], transcription activator-like effector nuclease [9], and the clustered regularly interspaced short palindromic repeat (CRISPR)/ CRISPR-associated (CRISPR/Cas) system [10-12], have improved gene modification activities markedly, including site-specific modification and gene knock-ins and knockouts. Gene editors have also enabled gene modification in porcine zygotes via direct injection into the cytoplasm [7]. However, micromanipulator systems for microinjections of gene editors or for nuclear transfer of donor cells in SCNT require sophisticated techniques, which limits the widespread generation of gene-modified pigs [6].

We recently developed the gene editing by electroporation of Cas9 protein (GEEP) method [13] in which the CRISPR/Cas9 system (Cas9 protein and guide RNA (gRNA)) is introduced into porcine zygotes by electroporation to disrupt a target gene. We also demonstrated that Cas9 mRNA electroporation into porcine zygotes resulted in a low gene-editing efficiency compared with Cas9 protein electroporation [13]. The electroporation procedure does not require sophisticated micromanipulation techniques. However, the efficiency of gene editing by GEEP and characteristics of piglets derived from electroporated zygotes have not been evaluated well, unlike in SCNT, in which the generation of genetically engineered pigs has been evaluated comprehensively [14]. To confirm the validity and efficacy of the approach, studies on the generation of genetically modified pigs from electroporated zygotes targeting various genes are required. GGTA1 knockout pigs have been generated by SCNT [15-18], handmade cloning [19], and CRISPR/ Cas9 microinjection into zygotes [20]; however, GGTA1modified pigs have not been established by the electroporation of the CRISPR/Cas9 system into zygotes.

In this study, we generated GGTA1-edited pigs using the GEEP method to establish a resource to facilitate pig-to-human xenotransplantation studies and to confirm the efficiency of the method in the establishment of lines of genetically modified pigs.

\section{Results}

Experiment 1: comparison of the gene editing efficiency using different gRNAs

Five types of gRNA were designed (gRNA1-5) to target GGTA1 (Fig. 1a). Each gRNA with the Cas9 protein was

\begin{tabular}{|c|c|c|c|}
\hline gRNA & Target Sequence & PAM & Strand \\
\hline gRNA1 & TGTTTTGGGAATACATCAAC & AGG & Sense \\
\hline gRNA2 & GGATTAAACCAGTCCACTAG & CGG & Antisense \\
\hline gRNA3 & AACTGTAATGGTTGTGTTTT & GGG & Sense \\
\hline gRNA4 & GAGAGCTTCCGCTAGTGGAC & TGG & Sense \\
\hline gRNA5 & AGACGCTATAGGCAACGAAA & AGG & Sense \\
\hline
\end{tabular}

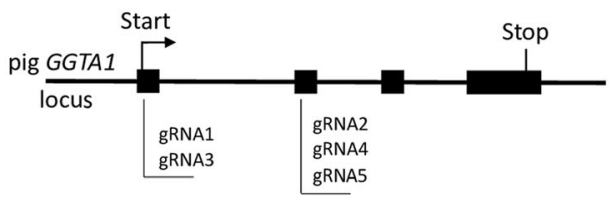

B

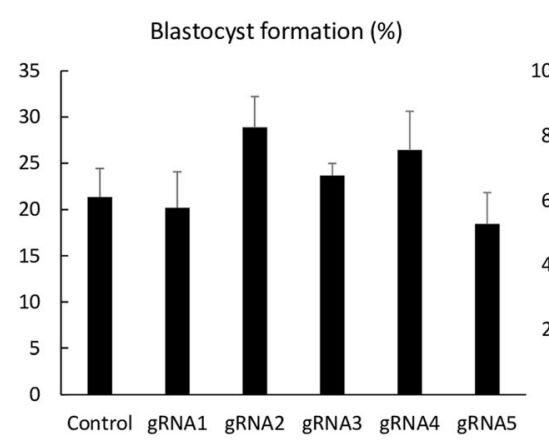

C

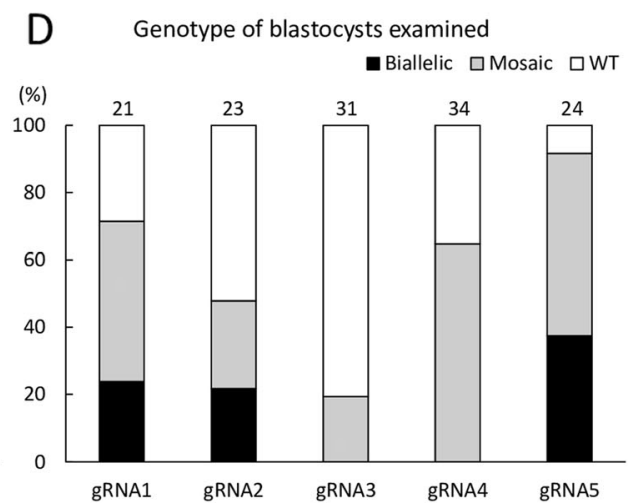

Fig. 1 Confirmation of the gRNA gene-targeting efficiency. a: gRNA sequences targeting the GGTA1 gene and genomic structure of the GGTA1 locus. b: Blastocyst formation rates of the electroporated zygotes. For each treatment group, four replicates with 199-243 oocytes per treatment were analyzed. Values of means \pm SEM are shown. c: Percentage of blastocysts carrying mutations in the GGTA1 target region after zygote electroporation with the Cas9 protein and each gRNA targeting GGTA1. The percentage of mutant blastocysts was defined as the ratio of mutant blastocysts to the total blastocysts. Percentages of mutant blastocysts was analyzed by chi-squared tests. ${ }^{\text {a-d }}$ Values with different superscripts differ significantly $(p<0.05)$ and labels containing the same letter mean no significant difference. d: Genotypes of blastocysts determined by TIDE. WT, wild-type; Biallelic, biallelic mutant; Mosaic, mosaic mutant. Numbers above the bars indicate the total number of blastocysts examined 
introduced into in vitro-fertilized zygotes by electroporation (five $1-\mathrm{ms}$ square pulses at $25 \mathrm{~V}$ ) of $100 \mathrm{ng} / \mu \mathrm{l}$ gRNA and $100 \mathrm{ng} / \mu \mathrm{l}$ Cas 9 protein. The electroporation conditions have been evaluated in our previous study [21]. Thereafter, the blastocyst formation rate from electroporated embryos with introduced gRNA and the genotypes of obtained blastocysts were analyzed to evaluate their ability to develop to the blastocyst stage and the genome editing efficiency of each gRNA. No significant differences in blastocyst formation rates were observed among the experimental groups (Fig. 1b). The genotypes of blastocysts were determined by sanger sequencing and subsequent analysis using the TIDE (tracking of indels by decomposition) bioinformatics package [22]. In the present study, blastocysts carrying more than one type of mutation and the wild-type (WT) sequence were defined as mosaics. The proportion of mutant blastocysts harboring mosaic and biallelic mutants after the introduction of gRNA5 was significantly higher than the proportions after the introduction of other gRNAs $(p<0.05)$ (Fig. 1c). Using the Cas9/gRNA5 complex, $37.5 \%$ of blastocysts carried biallelic mutations (Fig. 1d). Although mosaicism complicates phenotypic analysis, non-mosaic GGTA1-deficient pigs can be generated by the subsequent breeding of F0 pigs carrying mosaic mutations. Therefore, we selected gRNA5 for use in the generation of GGTA1-edited pigs.

\section{Experiment 2: generation and analysis of GGTA1-edited piglets}

Cas9 protein and gRNA5 were introduced into approximately 400 zygotes by electroporation. Then, these zygotes were transferred into the oviducts of two recipient gilts (approximately 200 zygotes/gilts). Both recipient gilts became pregnant and gave birth to a total of six piglets. A deep sequencing analysis of DNA samples derived from ear biopsy samples of the delivered piglets was performed to evaluate gene editing in the target gene and off-target events. Deep sequencing of the GGTA1 genomic regions flanking the target sites revealed that five out of the six piglets carried mutations in GGTA1 (Fig. 2). None of the five piglets (\#1, \#2, \#3, \#4, and \#5) had WT sequences; therefore, they were considered biallelic mutants. For an off-target analysis, we searched the whole genome sequence of the pig [UCSC (University of California, Santa Cruz) Genome Browser SGSC Sscrofa10.2/susScr3 assembly] for potential off-target sites and found six sites for gRNA5 with less than four mismatches/gaps (Fig. 3a). In a deepsequencing analysis, we did not detect mutations at offtarget sites in more than $99 \%$ of the amplicons (Fig. 3b). The remaining $1 \%$ was composed of a small number of amplicons $(<0.1 \%)$ carrying different sequences.

The expression levels of the Gal $\alpha(1,3)$ Gal epitope in heart, lung, liver, pancreas, and kidney tissues were assessed by staining using isolectin B4. The tissues derived from a GGTA1 biallelic mutant piglet (\#1) and its WT littermate (\#6) were stained with Alexa 488-labeled isolectin B4 to analyze $\operatorname{Gal} \alpha(1,3) \mathrm{Gal}$ epitope expression. A histological analysis indicated a deficiency in GGTA1 in the GGTA1 biallelic mutant piglet (Fig. 4). The deep sequencing analysis of the genomic DNA derived from the heart, lung, liver, pancreas, and kidney of piglet \#1 confirmed that these organs harbored the same type of mutations observed in the ear biopsy analyses; however, the frequency of these mutations varied with the organs (Fig. 5). Gal $\alpha(1,3) \mathrm{Gal}$ epitope expression was also assessed in ear biopsy samples from the other piglets $(\# 2, \# 3, \# 4$ and \#5) and compared with that from a WT littermate (\#6) (Fig. 6). Downregulation of Gal $\alpha(1,3) \mathrm{Gal}$ expression was observed in piglets \#2, \#3, and \#4. The expression of Gal $\alpha(1,3) \mathrm{Gal}$ in Piglet \#5 carrying in-frame mutation was similar to that in the WT.

Finally, we investigated whether the mutation detected in the F0 pig was inherited by the subsequent generation. We generated the $\mathrm{F} 1$ generation offspring by mating pig \#2 (male) with \#5 (female). Eight F1 piglets were delivered, and the piglets harbored mutations detected in the ear biopsy samples from pigs \#2 and \#5 (Fig. 7).

\begin{tabular}{|c|c|c|c|c|c|c|c|c|}
\hline gRNA & Piglet & Gender & Mutation & & Genome sequence* & Indels & Frequency $(\%)^{* *}$ & Mutation rate $(\%)^{* * *}$ \\
\hline \multirow{15}{*}{ gRNA5 } & & & & target & agaAGACGCTATAGGCAACGAAAAGGaacaaagaaaag & & & \\
\hline & \multirow{3}{*}{$\# 1$} & \multirow{3}{*}{ 우 } & \multirow{3}{*}{\multicolumn{2}{|c|}{ Bi-allelic }} & agaAGACGCTATAGGCAAC - - AAAGGAACAAAGAAAAG & $-2 \mathrm{bp}$ & $11220 / 23770(47.2 \%)$ & \multirow{3}{*}{$23170 / 23770(97.5 \%)$} \\
\hline & & & & & AGAAGACGCTATAGG -................ CAAAGAACAG & $-13 \mathrm{bp}$ & $7165 / 23770$ (30.1\%) & \\
\hline & & & & & AGAAGACGCTAT-......... AGGAACAAAGAAAAG & $-11 \mathrm{bp}$ & $4785 / 23770(20.1 \%)$ & \\
\hline & \multirow{2}{*}{ \#2 } & \multirow{2}{*}{$\sigma^{\pi}$} & \multirow{2}{*}{\multicolumn{2}{|c|}{ Bi-allelic }} & AGAAGACGCTATAGGCAACGTAAAAGGAACAAAGAAAAG & $+1 \mathrm{bp}(\mathrm{T})$ & $16940 / 33304(50.9 \%)$ & \multirow{2}{*}{$32470 / 33304(97.5 \%)$} \\
\hline & & & & & AGAAGACGCTATAGGCAACGGAAAAGGAACAAAGAAAAG & $+1 \mathrm{bp}(\mathrm{G})$ & $15530 / 33304(46.6 \%)$ & \\
\hline & \multirow{2}{*}{ \#3 } & \multirow[t]{2}{*}{$0^{\pi}$} & \multirow{2}{*}{\multicolumn{2}{|c|}{ Bi-allelic }} & AGAAGACGCTAT --..-- -AAAAGGAACAAAGAAAAG & $-8 \mathrm{bp}$ & $13426 / 26179(51.3 \%)$ & \multirow{2}{*}{$25480 / 26179(97.3 \%)$} \\
\hline & & & & & AGAAGACGCTATAGGCAACGCTAAAAGGAACAAAGAAAAG & $+2 \mathrm{bp}$ & $12054 / 26179(46.0 \%)$ & \\
\hline & \multirow{4}{*}{ \#4 } & \multirow{4}{*}{ 우 } & \multirow{4}{*}{\multicolumn{2}{|c|}{ Bi-allelic }} & AGAAGACGCTA-AGG A-C--AAAGGAACAAAGAAAAG & $-4 \mathrm{bp}, \mathrm{m} 1 \mathrm{bp}$ & $14935 / 33200(45.0 \%)$ & \multirow{4}{*}{$32412 / 33200(97.6 \%)$} \\
\hline & & & & & AGAAGACGCTATAGGCAAC-AAAAGGAACAAAGAAAAG & $-1 \mathrm{bp}$ & $14217 / 33200(42.8 \%)$ & \\
\hline & & & & & AGAAGACGCTATAGGCAAC--AAAGGAACAAAGAAAAG & $-2 \mathrm{bp}$ & $1682 / 33200(5.1 \%)$ & \\
\hline & & & & & AGAAGACGCTATAGGC - - - - AAGGAACAAAGAAAAG & $-6 b p$ & $1578 / 33200(4.8 \%)$ & \\
\hline & \multirow{2}{*}{ \#5 } & \multirow{2}{*}{ 우 } & \multirow{2}{*}{\multicolumn{2}{|c|}{ Bi-allelic }} & AGAAGACGCTATAGGAACAA GAACAAAAAGGAACAAAGGAACAAAGAAAAGGAGACA & $+14 \mathrm{bp}, \mathrm{m} 2 \mathrm{bp}$ & $19280 / 37679(51.2 \%)$ & \multirow{2}{*}{$36556 / 37679(97.0 \%)$} \\
\hline & & & & & AGAAGACGCTATAGGCAA GGAAACAAAGAAAAGGAACAAAGAAAAGGAACAAAGGAACAAAGAAAAG & $+30 \mathrm{bp}, \mathrm{m} 2 \mathrm{bp}$ & $17276 / 37679(45.9 \%)$ & \\
\hline & \#6 & 우 & WT & & AGAAGACGCTATAGGCAACGAAAAGGAACAAAGAAAAG & none & $28166 / 28992(97.2 \%)$ & - \\
\hline
\end{tabular}

Fig. 2 Deep sequence analysis of the GGTA1 target region in delivered piglets. *Nucleotides in blue and red represent the target sequences and PAM sequences of each gRNA, respectively. Nucleotides in green and yellow represent inserted and modified sequences, respectively. ${ }^{* *}$ The frequency was defined as the ratio of the number of amplicons to the total read number. ${ }^{* *}$ The mutation rate was defined as the ratio of the total number of mutant amplicons to the total read number. WT, wild-type; $\curvearrowright$, male;, , female 


\begin{tabular}{|c|c|c|c|}
\hline $\begin{array}{l}\text { Off-target } \\
\text { candidate }\end{array}$ & Genome sequence & Mismatch/Gap & locus (strand) \\
\hline & gaAGACGCTATAGGCAACGAAAAGG & & \\
\hline ОT1 & XXAGACTATATAGGCAATGAAAAGG & $3 \mathrm{bp}$ & Chr9:54784808-54784830 (+) \\
\hline ОТ 2 & XXAGAC-CTATAAGCAAAGAAATGG & $3 \mathrm{bp}$ & Chr13:19746422-19746443 (-) \\
\hline отз & XXAGACCCTATA-GCAAGGAAAGGG & $4 \mathrm{bp}$ & Chr18:21517307-21517328 (t) \\
\hline ОТ 4 & XXAGCCGCTATA-GCAACCAAAGGG & $3 \mathrm{bp}$ & ChrX:108694559-108694580 (+ \\
\hline OT5 & XXAGAAGCTATAGGCCAC-AAAGGG & $3 \mathrm{bp}$ & Chr11:82447766-82447787 (-) \\
\hline OT6 & XXAGACA-TATAGGCAA-GAAAAGG & $3 \mathrm{bp}$ & Chr4:9111872-9111892 (+) \\
\hline
\end{tabular}

B

\begin{tabular}{lcccc}
\hline & Piglet & Reads aligned & unmodified reads & unmodified (\%) \\
\hline GGTA1_OT1 & $\# 1$ & 29015 & 28846 & 99.42 \\
& $\# 2$ & 25530 & 25381 & 99.42 \\
& $\# 3$ & 27283 & 27120 & 99.40 \\
& $\# 4$ & 26222 & 26077 & 99.45 \\
& $\# 5$ & 21185 & 21054 & 99.38 \\
& $\# 6$ & 21181 & 21059 & 99.42 \\
\hline GGTA1_0T2 & $\# 1$ & 23160 & 23056 & 99.55 \\
& $\# 2$ & 21724 & 21622 & 99.53 \\
& $\# 3$ & 20612 & 20505 & 99.48 \\
& $\# 4$ & 22065 & 21977 & 99.60 \\
& $\# 5$ & 23412 & 23282 & 99.44 \\
& $\# 6$ & 18624 & 18539 & 99.54 \\
\hline GGTA1_0T4 & $\# 1$ & 23947 & 23745 & 99.16 \\
& $\# 2$ & 24883 & 24684 & 99.20 \\
& $\# 3$ & 21373 & 21222 & 99.29 \\
& $\# 4$ & 11172 & 11093 & 99.29 \\
& $\# 5$ & 22300 & 22101 & 99.11 \\
& $\# 6$ & 21157 & 21017 & 99.34 \\
\hline GGTA1_0T5 & $\# 1$ & 17216 & 17060 & 99.09 \\
& $\# 2$ & 21471 & 21262 & 99.03 \\
& $\# 3$ & 20004 & 19771 & 98.84 \\
& $\# 4$ & 17236 & 17065 & 99.01 \\
& $\# 5$ & 14914 & 14753 & 98.92 \\
& $\# 6$ & 15402 & 15250 & 99.01 \\
\hline GGTA1_0T6 & $\# 1$ & 16648 & 16542 & 99.36 \\
& $\# 2$ & 20554 & 20442 & 99.46 \\
& $\# 3$ & 19112 & 18999 & 99.41 \\
& $\# 4$ & 19229 & 19111 & 99.39 \\
& $\# 5$ & 18551 & 18413 & 99.26 \\
& $\# 6$ & 20099 & 19974 & 99.38 \\
\hline & & & &
\end{tabular}

Fig. 3 Off-target analysis of the delivered piglets via deep sequencing. a: Genome sequences and positions of possible off-target sites. Nucleotides in blue and red represent the target sequences and the PAM sequences of gRNA5, respectively. Nucleotides in green represent mismatches with the gRNA5 sequence. b: Frequency of the WT sequence at possible off-target sites

\section{Discussion}

In the present study, we successfully generated GGTA1 biallelic mutant pigs using the GEEP method based on the CRISPR/Cas9 system with high efficiency and no off-target events. The assessment of Galo(1,3)Gal epitope expression in ear biopsy samples and organ samples indicated that GGTA1 biallelic mutant pigs without inframe mutations exhibit the successful downregulation of the Galo(1,3)Gal epitope. Conversely, high frequency in-frame mutation (45.9\%) seemed to result in the expression of Gal $\alpha(1,3) \mathrm{Gal}$ in one biallelic mutant piglet (\#5).

Non-specific cleavage of off-target sequences are a major concern with respect to the practical implementation of the CRISPR/Cas9 system [23, 24]. In a deep sequencing analysis, more than $99 \%$ of the amplicons of potential off-target sites were made up of the WT sequence. The remaining $1 \%$ was composed of a small number of amplicons $(<0.1 \%)$ carrying different sequences. These were also detected when we analyzed a

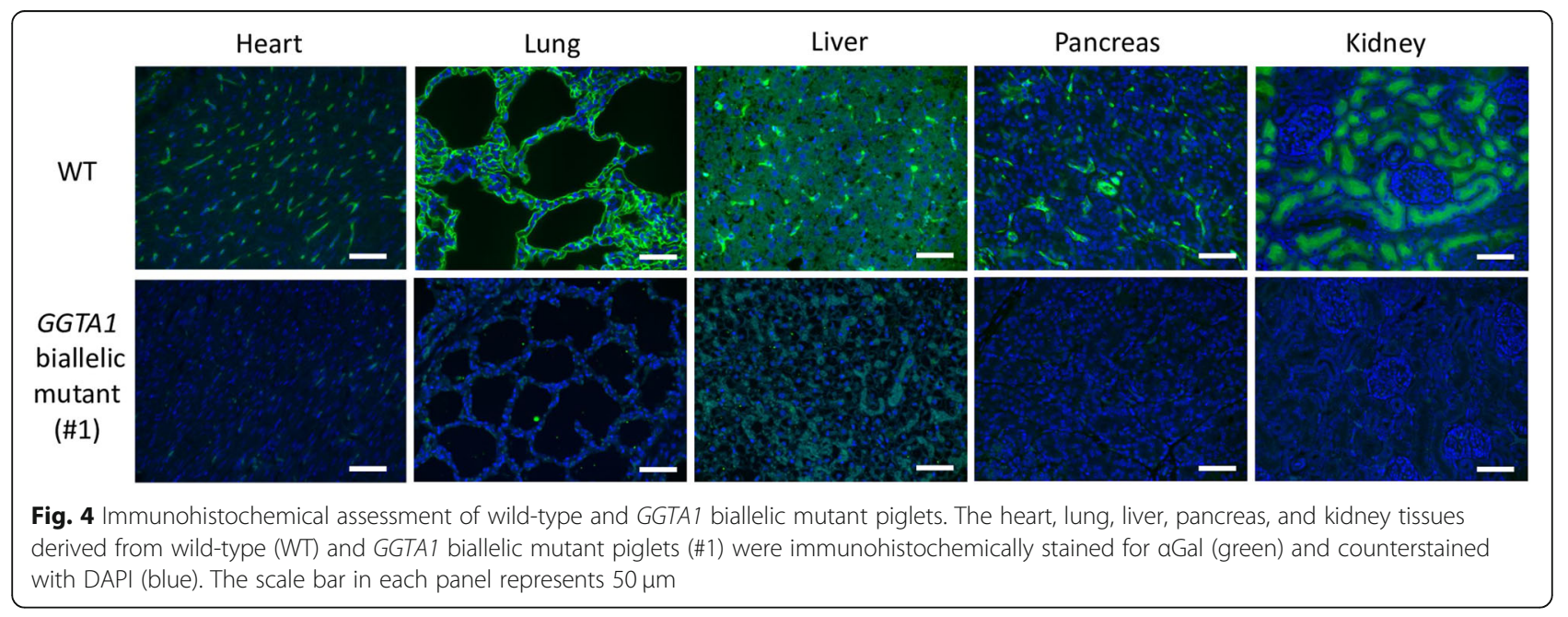




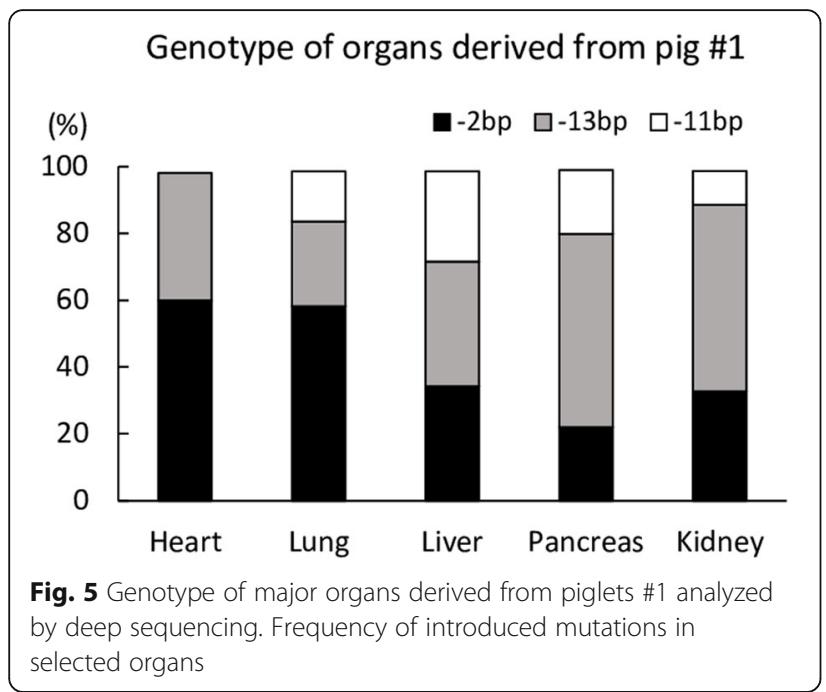

WT piglet by deep sequencing $[13,25]$, indicating that they may have been introduced by polymerase chain reaction (PCR) errors or sequencing errors. In addition, we introduced the CRISPR/Cas9 system into 1-cell-stage zygotes, indicating that off-target mutation carrying less than $0.1 \%$ of the sequences in individual offspring is difficult to achieve. Therefore, we concluded that no offtarget events were detected in GGTA1 mutant pigs generated in the present study. Varying degrees of off-target effects by CRISPR/Cas9 have been observed in cells [26, 27], and whole-genome sequencing analyses have identified off-target events in founder gene-modified mice generated using the CRISPR/Cas9 system [28]. Another study reported that off-target events are rare in gene-modified nonhuman primates generated using the CRISPR/Cas9 system [29]. In our previous study of the generation of Myostatin mutant pigs, no off-target events were observed [13]. Recently, mutant Cas9 nucleases with high specificity have been designed [30-32]. Such improvements could reduce off-target events, which should be carefully evaluated in gene-modified pigs supplied as founders.

In the present study, we achieved the efficient generation of GGTA1 biallelic-mutant pigs using the GEEP method, in which the CRISPR/Cas9 system is introduced into zygotes by electroporation. The electroporation procedure does not require any sophisticated micromanipulation techniques, when compared with microinjection and SCNT medicated procedures, and the results of the present study demonstrated that the GEEP method is a promising approach for the generation of biallelic mutants with high efficiency. However, we have previously observed that the introduction of CRISPR/Cas9 into zygotes results in a high frequency of mosaicism in blastocysts and obtained piglets [13, 33, 34]. Based on an analysis of DNA derived from ear biopsy samples, piglet \#1 showed three types of mutation; however, there could be differences in editing variants among the different organs. We performed a deep-sequencing analysis of the selected organs from piglet $\# 1$ for genotype
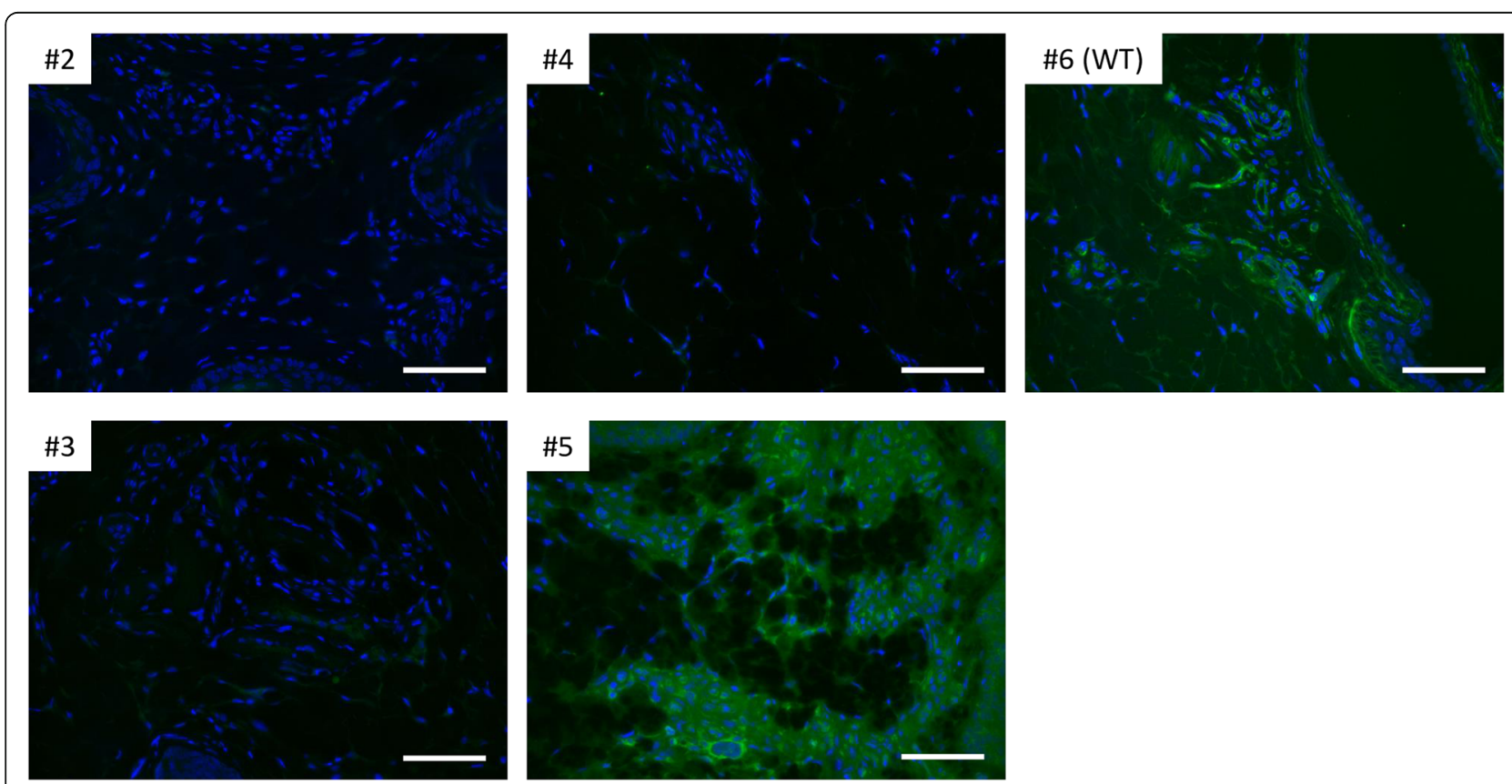

Fig. 6 Comparison of the expression of aGal epitope in GGTA1 mutant piglets with various genotypes by immunohistochemical assessment. The ear biopsy derived from wild-type (WT) and GGTA1 biallelic mutant piglets (\#2, \#3, \#4, and \#5) were immunohistochemically stained for aGal (green) and counterstained with DAPI (blue). The scale bar in each panel represents $50 \mu \mathrm{m}$ 


\begin{tabular}{|c|c|c|c|}
\hline & & Genome sequence & Indels \\
\hline F1 piglets & target & agaAGACGCTATAGGCAACGAAAAGGaacaaagaaaag & \\
\hline \multirow{2}{*}{\multicolumn{2}{|c|}{$\# 1$}} & AGAAGACGCTATAGGCAACGGAAAAGGAACAAAGAAAAG & $+1 \mathrm{bp}(\mathrm{G})$ \\
\hline & & AGAAGACGCTATAGGAACAA GAACAAAAAGGAACAAAGGAACAAAGAAAAGGAGACA & $+14 \mathrm{bp}, \mathrm{m} 2 \mathrm{bp}$ \\
\hline \multirow{2}{*}{\multicolumn{2}{|c|}{ \#2 }} & AGAAGACGCTATAGGCAACGGAAAAGGAACAAAGAAAAG & $+1 \mathrm{bp}(\mathrm{G})$ \\
\hline & & AGAAGACGCTATAGGAACAA GAACAAAAAGGAACAAAGGAACAAAGAAAAGGAGACA & $+14 \mathrm{bp}, \mathrm{m} 2 \mathrm{bp}$ \\
\hline \multirow{2}{*}{\multicolumn{2}{|c|}{ \#3 }} & AGAAGACGCTATAGGCAACGTAAAAGGAACAAAGAAAAG & $+1 \mathrm{bp}(\mathrm{T})$ \\
\hline & & AGAAGACGCTATAGGCAA GGAAACAAAGAAAAGGAACAAAGAAAAGGAA AAAGGAACAAAGAAAAG & $+30 \mathrm{bp}, \mathrm{m} 2 \mathrm{bp}$ \\
\hline \multirow{2}{*}{\multicolumn{2}{|c|}{ \#4 }} & AGAAGACGCTATAGGCAACGGAAAAGGAACAAAGAAAAG & $+1 \mathrm{bp}(\mathrm{G})$ \\
\hline & & AGAAGACGCTATAGGAACAA GAACAAAAAGGAACAAAGGAACAAAGAAAAGGAGACA & $+14 \mathrm{bp}, \mathrm{m} 2 \mathrm{bp}$ \\
\hline \multirow{2}{*}{\multicolumn{2}{|c|}{ \#5 }} & AGAAGACGCTATAGGCAACGTAAAAGGAACAAAGAAAAG & $+1 \mathrm{bp}(\mathrm{T})$ \\
\hline & & AGAAGACGCTATAGGCAA GGAAACAAAGAAAAGGAACAAAGAAAAGGAACAAAGGAACAAAGAAAAG & $+30 \mathrm{bp}, \mathrm{m} 2 \mathrm{bp}$ \\
\hline \multirow{2}{*}{\multicolumn{2}{|c|}{ \#6 }} & AGAAGACGCTATAGGCAACGGAAAAGGAACAAAGAAAAG & $+1 \mathrm{bp}(\mathrm{G})$ \\
\hline & & AGAAGACGCTATAGGAACAA GAACAAAAAGGAACAAAGGAACAAAGAAAAGGAGACA & $+14 \mathrm{bp}, \mathrm{m} 2 \mathrm{bp}$ \\
\hline \multirow{2}{*}{\multicolumn{2}{|c|}{ \#7 }} & AGAAGACGCTATAGGCAACGTAAAAGGAACAAAGAAAAG & $+1 \mathrm{bp}(\mathrm{T})$ \\
\hline & & AGAAGACGCTATAGGCAA GGAAACAAAGAAAAGGAACAAAGAAAAGGAACAAAGGAACAAAGAAAAG & $+30 \mathrm{bp}, \mathrm{m} 2 \mathrm{bp}$ \\
\hline \multirow{2}{*}{\multicolumn{2}{|c|}{ \#8 }} & AGAAGACGCTATAGGCAACGTAAAAGGAACAAAGAAAAG & $+1 \mathrm{bp}(\mathrm{T})$ \\
\hline & & AGAAGACGCTATAGGCAA GGAAACAAAGAAAAGGAACAAAGAAAAGGAACAAAGGAACAAAGAAAAG & $+30 \mathrm{bp}, \mathrm{m} 2 \mathrm{bp}$ \\
\hline
\end{tabular}

confirmation. We observed that the piglet harbored mutations, as observed in the ear biopsy analysis, in its major organs at various frequencies. Our previous study demonstrated mosaicism of major organs with frequencies similar to those observed in the results of the ear biopsy analysis [35]. The frequency of genotype varies with organ in genetically modified F0 pigs, indicating that a careful observation of WT sequence/in-frame mutation in the genomic DNA is an essential step to apply these organs for transplantation.

The assessment of Gal $\alpha(1,3) \mathrm{Gal}$ expression in the major organs of piglet \#1 demonstrated downregulation of Gal $\alpha(1,3)$ Gal expression; however, the heart and liver tissues contained a Gal $\alpha(1,3)$ Gal-positive region. Such residual amounts of $\mathrm{Gal} \alpha(1,3) \mathrm{Gal}$ epitope reactivity, which may not be tissue specific, have also been observed in GGTA1 knockout pigs [36] and cells [37]. Previous studies on GGTA1 deficient pigs could not detect Gal $\alpha(1,3)$ Gal expression on the vascular endothelium using the IB4 [16, 38]; therefore the $\alpha 1,3$-Galactosyltransferase has been believed to be the only enzyme that synthesizes $\mathrm{Gal}(1,3) \mathrm{Gal}$ [39]. Milland et al. suggested that isoglobotrihexosylceramide 3 synthase (iGb3S) could also be responsible for Gal $\alpha(1,3) \mathrm{Gal}$ expression in GGTA1 deficient mice and pigs as an alternative pathway [40]. However, Gal $\alpha(1,3)$ Gal expression was observed in GGTA1 and $i G b 3 s$ double-knockout pigs [41]. Although Gal $\alpha(1,3)$ Gal expression was successfully downregulated by GGTA1 modification, another pathway could have facilitated the expression of $G a l \alpha(1,3) G a l$ epitope in GGTA1-deficient pigs.

The direct introduction of the CRISPR/Cas9 system by zygote microinjection also suffers a risk of mosaicism $[20,42]$. Mosaicism in the founder generation requires subsequent breeding for phenotypic analyses. In this study, inheritance analysis of GGTA1-modified F0 pigs demonstrated that the spectra of alleles present in the gametes was similar as the alleles observed in the ear biopsy; therefore, we will generate nonmosaic GGTA1 deficient pigs by mating using F0 pigs harboring the desired genotypes. However, subsequent breeding of F0 lines is cost- and time-intensive. Gene modifications by Cas9 protein/gRNA complexes remaining active during later developmental stages, following cleavage, can lead to mosaicism [43], which is presumed to be the reason for the more than two different genotypes in piglet \#1 and \#4 in the present study. This is expected to be reduced by the early delivery of the CRISPR/Cas9 system into zygotes. We previously evaluated the gene editing efficiency of the CRISPR/Cas9 system introduced before in vitro fertilization for the production of non-mosaic mutants [44]. Other studies have demonstrated that the microinjection of the CRISPR/Cas9 system into immature oocytes successfully reduces mosaicism [45, 46]. A combination of these strategies will reduce mosaicism by the one-step generation of gene-knockout founder pigs via microinjection and electroporation techniques.

GGTA1 inactivation is an essential first step for controlling hyperacute rejection in pig-human xenotransplantation. However, other xenogeneic antigens, including beta-1,4- $N$-acetyl-galactosaminyltransferase 1 (B4GALNT) [47] and $N$-glycolylneuraminic acid synthesized by cytidine monophospho- $N$-acetylneuraminic acid hydroxylase (CMAH) $[48,49]$, also need to be eliminated to prolong organ survival. The triple knockout of porcine GGTA1, CMAH, and B4GALNT2 has been achieved by SCNT and significantly reduces human IgG and IgM antibody binding to porcine peripheral blood monocytes, red blood cells [50-52], and the pericardium [53]. In addition, to prevent hyperacute rejection by controlling 
complement activation, the expression of human complement regulators in pigs has been studied [3, 54]. Other anti-inflammatory and anti-apoptosis-related genes in humans have also been expressed in pigs [5557]. Xenograft rejection of these organs from genetically modified pigs to monkey and baboon models has been successfully delayed [58-60]. Multiple gene modifications, including knock-ins of human genes, will be essential for the maintenance of the function of xenotransplanted organs.

\section{Conclusion}

Our method to establish GGTA1-modified pigs harboring mutations in their germ lines and without antigenrelated hyperacute rejection is an efficient alternative to SCNT. The GEEP method does not require complex procedures. However, multiple gene-modified pigs generated using this method have not been established. To generate gene-modified pigs for pig-to-human xenotransplantation, further improvements aimed at the generation of multiple gene modifications, including knockins of human genes, in porcine zygotes, are required.

\section{Methods}

\section{Animals}

All animal care and experimental procedures, including the determination of experimental endpoints, were performed in accordance with the Guidelines for Animal Experiments of Tokushima University. All animals were housed and maintained in accordance with Institutional Animal Care and Use Committee guidelines. Two sexually mature Landrace gilts were obtained from the Tokushima Prefectural Livestock Research Institute (Tokushima, Japan) as recipients. Pigs were housed in a temperature-controlled room $\left(25 \pm 3^{\circ} \mathrm{C}\right)$ under a 12 -h light/12-h dark cycle with free access to water and were provided with commercial feed (JA Nishinihon Kumiai Shiryou, Hyogo, Japan). The health condition of all pigs was observed daily at feeding by the animal husbandry staff under the supervision of an attending veterinarian. To minimize animal suffering, all surgical procedures were performed under anesthesia by the intramuscular injection of $10 \mathrm{mg} / \mathrm{kg}$ ketamine (Ketalar, ketamine hydrochloride, Daiichi Sankyo Pharmaceutical, Tokyo, Japan) and continuous inhalation of 2 to $3 \%$ isoflurane (Mylan, Osaka, Japan) in the operation room. Euthanasia was performed by the intravenous injection of a potassium chloride solution $(3 \mathrm{mmol} / \mathrm{kg})$ under deep anesthesia by isoflurane according to the American Veterinary Medical Association Guidelines for the Euthanasia of Animals.

In this study, we obtained a total of six piglets. Five piglets (\#1, \#2, \#3, \#4, and \#5) carried mutations in GGTA1 gene, and one piglet was WT. For collecting tissue samples, piglets \#1 and \#6 were euthanized by the intravenous injection of a potassium chloride solution $(3 \mathrm{mmol} / \mathrm{kg}$ ) under deep anesthesia by isoflurane. Piglets $\# 2$, \#3, \#4, and \#5 were maintained as a founder.

\section{Oocyte collection, in vitro maturation, and fertilization}

Pig ovaries were obtained from prepubertal gilts (Landrace $\times$ Large White $\times$ Duroc breeds) at a local slaughterhouse and were transported in physiological saline within $1 \mathrm{~h}$ to the laboratory at $30^{\circ} \mathrm{C}$. Ovaries were washed three times with prewarmed physiological saline solution supplemented with $100 \mathrm{IU} / \mathrm{ml}$ penicillin G potassium (Meiji, Tokyo, Japan) and 0.1 $\mathrm{mg} / \mathrm{ml}$ streptomycin sulfate (Meiji). Follicles with diameters of 3-6 $\mathrm{mm}$ on the ovarian surface were sliced on a sterilized dish using a surgical blade, and cumulus-oocyte complexes (COCs) were visualized and collected under a stereomicroscope. Approximately 50 COCs were cultured in $500 \mu \mathrm{l}$ of maturation medium consisting of tissue culture medium 199 with Earle's salts (TCM 199; Gibco/Invitrogen Co., Carlsbad, CA, USA) supplemented with $10 \%$ (v/ v) porcine follicular fluid, $0.6 \mathrm{mM}$ cysteine (Sigma-Aldrich, St. Louis, MO, USA), $50 \mu \mathrm{M} \beta$-mercaptoethanol (Wako Pure Chemical Industries Ltd., Osaka, Japan), $50 \mu \mathrm{M}$ sodium pyruvate (Sigma-Aldrich), $2 \mathrm{mg} / \mathrm{ml} \mathrm{D-}$ sorbitol (Wako Pure Chemical Industries Ltd.), $10 \mathrm{IU} /$ $\mathrm{ml}$ equine chorionic gonadotropin (eCG; Kyoritu Seiyaku, Tokyo, Japan), $10 \mathrm{IU} / \mathrm{ml}$ human chorionic gonadotropin (hCG; Kyoritu Seiyaku), and $50 \mu \mathrm{g} / \mathrm{ml}$ gentamicin (Sigma-Aldrich), then covered with mineral oil (Sigma-Aldrich) for $22 \mathrm{~h}$ in 4 -well dishes (Nunc A/S, Roskilde, Denmark). The COCs were transferred into a maturation medium without hormones for an additional $22 \mathrm{~h}$. COCs were incubated at $39^{\circ} \mathrm{C}$ in a humidified incubator containing $5 \% \mathrm{CO}_{2}$.

The matured oocytes were subjected to in vitro fertilization as described previously [61]. Briefly, frozenthawed ejaculated spermatozoa were transferred into 5 $\mathrm{ml}$ of porcine fertilization medium (PFM; Research Institute for the Functional Peptides Co., Yamagata, Japan) and washed by centrifugation at $500 \times g$ for $5 \mathrm{~min}$. The pelleted spermatozoa were resuspended in fertilization medium and adjusted to $1 \times 10^{6}$ cells $/ \mathrm{ml}$. Then, approximately 50 oocytes were transferred to $500 \mu$ l of spermcontaining fertilization medium, covered with mineral oil in 4-well dishes, and co-incubated for $5 \mathrm{~h}$ at $39^{\circ} \mathrm{C}$ in a humidified incubator containing $5 \% \mathrm{CO}_{2}, 5 \% \mathrm{O}_{2}$, and $90 \% \mathrm{~N}_{2}$. After co-incubation, the putative zygotes were denuded from the cumulus cells and the attached spermatozoa by mechanical pipetting, transferred to porcine zygote medium (PZM-5; Research Institute for the Functional Peptides Co.), and cultured for $7 \mathrm{~h}$ until electroporation. 


\section{Electroporation}

Electroporation was performed as described previously [13]. Briefly, an electrode (LF501PT1-20; BEX, Tokyo, Japan) was connected to a CUY21EDIT II electroporator (BEX) and was set under a stereoscopic microscope. The inseminated 50 zygotes were washed with Opti-MEM I solution (Gibco/Invitrogen, Carlsbad, CA, USA) and were placed in a line in the electrode gap in a chamber slide filled with $10 \mu \mathrm{l}$ of Nuclease-Free Duplex Buffer (IDT; Integrated DNA Technologies, Coralville, IA, USA) containing $100 \mathrm{ng} / \mu \mathrm{l}$ gRNA (Alt-R CRISPR crRNAs and tracrRNA, chemically modified and lengthoptimized variants of the native guide RNAs purchased from IDT) targeting GGTA1 and $100 \mathrm{ng} / \mu \mathrm{l}$ Cas 9 protein (Guide-it Recombinant Cas9; Takara Bio, Shiga, Japan). According to manufacturer's instruction, crRNA contains chemical modifications to protect it from degradation by cellular RNases, and tracrRNA contains chemical modifications conferring high nuclease resistance. gRNAs were designed using the CRISPRdirect webtool (https://crispr.dbcls.jp/) [62]. To minimize offtarget effects, the 12 bases at the $3^{\prime}$ end of the designed gRNAs had no identical sequence matches to the pig genome other than the target region of GGTA1, as determined using the COSMID webtool (https://crispr. bme.gatech.edu/), which scores and ranks off-target candidate sequences based on the locations and numbers of base mismatches, deletions, and insertions, when compared to the gRNA sequence [63].

After electroporation (five 1-ms square pulses at $25 \mathrm{~V}$ ), the zygotes were washed with PZM-5 and were cultured until embryo transfer (for $12 \mathrm{~h}$ ) or for 3 days. The embryos that were cultured for 3 days were subsequently incubated in porcine blastocyst medium (PBM; Research Institute for the Functional Peptides Co.) for 4 days to evaluate their ability to develop to the blastocyst stage and for blastocyst genotyping. As a control, some of the inseminated zygotes were cultured with PZM-5 and PBM for 7 days without electroporation. Zygotes and embryos were incubated at $39^{\circ} \mathrm{C}$ in a humidified incubator containing $5 \% \mathrm{CO}_{2}, 5 \% \mathrm{O}_{2}$, and $90 \% \mathrm{~N}_{2}$.

\section{Analysis of the targeted gene after electroporation}

Genomic DNA was isolated from blastocysts by boiling in a $50 \mathrm{mM} \mathrm{NaOH}$ solution. After neutralization, the genomic regions flanking the gRNA target sequences were PCR-amplified by the following specific primers: gRNA1 and gRNA3, 5'- AGTCAGGATG CTTCCCCTTT - 3' (forward) and 5' - AAGCTG GTGACTTGGCTGAT - 3' (reverse), gRNA2, gRNA4, and gRNA5, 5' - AAAAGGGGAGCACTGAACCT - 3' (forward) and 5' - ATCCGGACCCTGTTTTAAGG 3' (reverse). The PCR products were extracted by agarose gel electrophoresis. The targeted genomic regions were directly sequenced. Sanger sequencing was performed using a BigDye Terminator Cycle Sequencing Kit ver. 3.1 (Thermo Fisher Scientific, Waltham, MA, USA) and the ABI 3500 Genetic Analyzer (Applied Biosystems, Foster City, CA, USA). The TIDE bioinformatics package [22] was used to determine the genotypes of blastocysts. Blastocysts were classified as having biallelic mutations (carrying no WT sequences), mosaics (carrying more than one type of mutation and the WT sequence), or WT (carrying only the WT sequence).

\section{Embryo transfer}

Recipient gilts, the estrous cycles of which had been synchronized, were prepared for embryo transfer as described previously [64]. In brief, $0.2 \mathrm{mg}$ of cloprostenol (Planate, MSD Animal Health, Tokyo, Japan) was given by intramuscular (i.m.) injection to pregnant gilts 35 to 53 days after the day of insemination. Subsequently, the second i.m. injection of $0.2 \mathrm{mg}$ of cloprostenol and i.m. injection of $1000 \mathrm{IU}$ of eCG (PMSA for Animal, ZENOAQ, Fukushima, Japan) were given to the gilts 24 $\mathrm{h}$ after the first injection of cloprostenol. At $72 \mathrm{~h}$ after the eCG i.m. injection, 1500 IU of hCG (Gestron 1500, Kyoritsu Seiyaku) was administered to the gilts. Approximately $72 \mathrm{~h}$ after the eCG i.m. injection, one- to two-cell stage embryos which were electroporated approximately $12 \mathrm{~h}$ before the embryo transfer were transferred into the oviducts of a recipient gilt under anesthesia. The gilts were placed in the supine position and the surgical area was disinfected with povidone-iodine (Meiji Seika Pharma, Tokyo, Japan). Generally, spontaneous ovulation rate, which varies across breeds, ranges from 10 to $23[65,66]$. Viability and quality of in vitro-derived embryos are inferior to those of in vivo-derived embryos [67], and blastocyst formation rate was around $20 \%$ in the present study. Therefore, approximately 100 zygotes were transferred to each oviduct, resulting in the transfer of 200 zygotes (equivalent to approximately 40 blastocysts) per gilt under sterile conditions.

\section{Mutation analysis in piglets by deep sequencing}

The ear biopsies were collected from piglets under anesthesia by continuous inhalation of 2 to 3\% isoflurane. Genomic DNA was isolated from the ear biopsies by boiling in a $50 \mathrm{mM} \mathrm{NaOH}$ solution. After neutralization, the genomic regions that flanked the gRNA target sequences were amplified by two-step PCR by specific primers ( $\mathrm{S} 1$ Table) and the Index PCR Primers following the manufacturer's instructions (Illumina, Hayward, CA, USA). After gel purification, the amplicons were subjected to MiSeq sequencing using the MiSeq Reagent Kit v. 2 (250 cycles) (Illumina, San Diego, CA, USA). The mutation rates were defined as 
the ratio of the number of mutant amplicons to the total read number. A small number of amplicons carrying different sequences, that were also detected in WT samples were excluded as sequencing errors. Piglets that carried no WT sequences were classified as having biallelic mutations. Those carrying more than one type of mutation and the WT sequence were classified as mosaics. Piglets that carried only the WT sequence were classified as WT.

For the evaluation of genotype in major organs, genomic DNA isolated from the heart, lung, liver, pancreas, and kidney were amplified by two-step PCR and subjected to MiSeq sequencing as described above.

\section{Off-target effects determined by deep-sequencing}

Off-target analysis was performed as described previously [13]. The COSMID webtool was used to determine the predicted off-target candidates. The genomic regions flanking potential off-target sites were amplified by twostep PCRs using specific primers (S2 Table) and the Index PCR Primers following the manufacturer's instructions (Illumina), and subjected to a MiSeq sequencing analysis. Indel or substituted mutations were measured within a 5-bp window around the predicted Cas9 cleavage site in each off-target sites using CRISPResso [68] to minimize false-positive classification. A small number of amplicons carrying different sequences that were also detected in a WT sample were excluded as sequencing errors.

\section{Immunohistochemical assessment of piglets}

A GGTA1 biallelic mutant piglet and its WT littermate were euthanized by the intravenous injection of a potassium chloride solution $(3 \mathrm{mmol} / \mathrm{kg})$ under the intramuscular injection of $10 \mathrm{mg} / \mathrm{kg}$ ketamine and subsequent deep anesthesia by isoflurane. Tissues were dissected, fixed in a 4\% paraformaldehyde neutral-buffered solution (Wako, Osaka, Japan), and manually embedded in paraffin. The paraffin-embedded sections were deparaffinized in xylene and rehydrated in decreasing concentrations of ethanol. Blocking treatment was performed by incubation with $0.1 \%$ bovine serum albumin in phosphate buffered saline supplemented with $1 \mathrm{mM} \mathrm{CaCl}, 1 \mathrm{mM}$ $\mathrm{MgCl}_{2}$, and $1 \mathrm{mM} \mathrm{MnCl}$ for $30 \mathrm{~min}$ at $25^{\circ} \mathrm{C}$. The sections were incubated overnight with $10 \mu \mathrm{g} / \mathrm{ml}$ isolectin B4-Alexa 488 (Thermo Fisher Scientific) at $4{ }^{\circ} \mathrm{C}$ and were subsequently fixed with $10 \%$ neutral formalin. The nuclei were counterstained with DAPI.

\section{Statistical analyses}

Percentage data for embryos that developed to the blastocyst stage were subjected to arcsine transformation before analysis of variance (ANOVA). The transformed data were evaluated by ANOVA, followed by protected
Fisher's least significant difference tests. The analysis was performed using StatView software (Abacus Concepts, Berkeley, CA, USA). The percentages of mutated blastocysts were analyzed using chi-squared tests. Differences with a probability value $(p)$ of 0.05 or less were considered statistically significant.

\section{Supplementary information}

Supplementary information accompanies this paper at https://doi.org/10. 1186/s12896-020-00638-7.

Additional file 1 S1 Table. Oligonucleotide sequences used for analysis of the introduced mutations in piglets by deep sequencing. S2 Table. Oligonucleotide sequences used for off-target analysis by deepsequencing.

\section{Abbreviations}

ANOVA: ANalysis Of VAriance; B4GALNT: Beta-1,4-N-acetylGALactosaminylTransferase 1; Cas9: CRISPR-associated system 9; CMAH: Cytidine Monophospho - N - acetylneuraminic Acid Hydroxylase; COCs: Cumulus-Oocyte Complexes; CRISPR: Clustered Regularly Interspaced Short Palindromic Repeat; eCG: Equine Chorionic Gonadotropin; gRNA: Guide RNA; GEEP: Gene Editing by Electroporation of Cas9 Protein;

GGTA1: Glycoprotein Galactosyl Transferase Alpha 1,3; hCG: Human Chorionic Gonadotropin; iGb3s: Isoglobotrihexosylceramide 3 synthase; PAM: Protospacer Adjacent Motif; PBM: Porcine Blastocyst Medium; PCR: Polymerase Chain Reaction; PFM: Porcine Fertilization Medium; PZM5: Porcine zygote medium-5; SCNT: Somatic Cell Nuclear Transfer; TCM199: Tissue Culture Medium 199; TIDE: Tracking of Indels by DEcomposition; WT: Wild-type

\section{Acknowledgments}

We thank the Nippon Food Packer, K. K. Shikoku (Tokushima, Japan) for supplying the pig ovaries.

\section{Authors' contributions}

F.T., M.H., and T.O. conceived the study and wrote the manuscript. F.T. and M.H. performed the majority of experiments. T.O. designed the study, coordinated all of the experiments, and reviewed the manuscript. M.H. performed the phenotypic analysis. N.T.N. contributed to the laboratory work and statistical analysis. O.S., T.K., and M.D. designed the study and revised the manuscript. All of the authors read and accepted the manuscript.

\section{Funding}

This study was supported in part by the Program of Open Innovation Platform with Enterprises, Research Institute and Academia (OPERA) grant number JPMJOP1613 from the Japan Science and Technology Agency (JST), and KAKENHI grant number JP17H03938, JP18K12062 and JP19K16014 from the Japan Society for the Promotion of Science (JSPS). The funders had no role in study design, data collection and analysis, decision to publish, or preparation of the manuscript.

\section{Availability of data and materials}

The datasets used and/or analysed during the current study are available from the corresponding author on reasonable request.

\section{Ethics approval and consent to participate}

The animal experiments were approved by the Institutional Animal Care and Use Committee of Tokushima University (approval number: T28-21).

Consent for publication

Not applicable.

Competing interests

The authors declare that they have no competing interests. 


\section{Author details}

'Laboratory of Animal Reproduction, Faculty of Bioscience and Bioindustry, Tokushima University, 2272-1 Ishii, Myozai-gun, Tokushima 779-3233, Japan. ${ }^{2}$ Research and Development Center, Otsuka Pharmaceutical Factory, Inc., 115 Muya-cho, Naruto, Tokushima 772-8601, Japan.

Received: 29 February 2020 Accepted: 10 August 2020

Published online: 18 August 2020

\section{References}

1. Niemann H, Kues WA. Application of transgenesis in livestock for agriculture and biomedicine. Anim Reprod Sci. 2003;79:291-317.

2. Klymiuk N, Aigner B, Brem G, Wolf E. Genetic modification of pigs as organ donors for xenotransplantation. Mol Reprod Dev. 2010;77:209-21.

3. Zeyland J, Lipinski D, Slomski R. The current state of xenotransplantation. J Appl Genet. 2015;56:211-8

4. Cooper DK. Xenoantigens and xenoantibodies. Xenotransplantation. 1998;5: 6-17.

5. Galili U, Shohet SB, Kobrin E, Stults CL, Macher BA. Man, apes, and Old World monkeys differ from other mammals in the expression of alphagalactosyl epitopes on nucleated cells. J Biol Chem. 1988;263:17755-62.

6. Fan N, Lai L. Genetically modified pig models for human diseases. J Genet Genomics. 2013;40:67-73.

7. Tan W, Proudfoot C, Lillico SG, Whitelaw CB. Gene targeting, genome editing: from Dolly to editors. Transgenic Res. 2016;25:273-87.

8. Kim YG, Cha J, Chandrasegaran S. Hybrid restriction enzymes: zinc finger fusions to Fok I cleavage domain. Proc Natl Acad Sci U S A. 1996;93:115660 .

9. Christian M, Cermak T, Doyle EL, Schmidt C, Zhang F, Hummel A, Bogdanove AJ, Voytas DF. Targeting DNA double-strand breaks with TAL effector nucleases. Genetics. 2010;186:757-61.

10. Cong L, Ran FA, Cox D, Lin S, Barretto R, Habib N, Hsu PD, Wu X, Jiang W, Marraffini LA, Zhang F. Multiplex genome engineering using CRISPR/Cas systems. Science. 2013;339:819-23.

11. Mali P, Yang L, Esvelt KM, Aach J, Guell M, DiCarlo JE, Norville JE, Church GM. RNA-guided human genome engineering via Cas9. Science. 2013;339: 823-6.

12. Jinek M, East $A$, Cheng $A$, Lin $S, M a ~ E$, Doudna J. RNA-programmed genome editing in human cells. Elife. 2013;2:e00471.

13. Tanihara F, Takemoto T, Kitagawa E, Rao S, Do LT, Onishi A, Yamashita Y, Kosugi C, Suzuki H, Sembon S, Suzuki S, Nakai M, Hashimoto M, Yasue A Matsuhisa M, Noji S, Fujimura T, Fuchimoto D, Otoi T. Somatic cell reprogramming-free generation of genetically modified pigs. Sci Adv. 2016; 2:e1600803.

14. Kurome M, Geistlinger L, Kessler B, Zakhartchenko V, Klymiuk N, Wuensch A, Richter A, Baehr A, Kraehe K, Burkhardt K, Flisikowski K, Flisikowska T, Merkl C, Landmann M, Durkovic M, Tschukes A, Kraner S, Schindelhauer D, Petri T, Kind A, Nagashima $\mathrm{H}$, Schnieke A, Zimmer R, Wolf E. Factors influencing the efficiency of generating genetically engineered pigs by nuclear transfer: multi-factorial analysis of a large data set. BMC Biotechnol. 2013;13:43.

15. Cheng W, Zhao H, Yu H, Xin J, Wang J, Zeng L, Yuan Z, Qing Y, Li H, Jia B, Yang C, Shen Y, Zhao L, Pan W, Zhao HY, Wang W, Wei HJ. Efficient generation of GGTA1-null Diannan miniature pigs using TALENs combined with somatic cell nuclear transfer. Reprod Biol Endocrinol. 2016;14:77.

16. Phelps CJ, Koike C, Vaught TD, Boone J, Wells KD, Chen SH, Ball S, Specht SM, Polejaeva IA, Monahan JA, Jobst PM, Sharma SB, Lamborn AE, Garst AS, Moore M, Demetris AJ, Rudert WA, Bottino R, Bertera S, Trucco M, Starzl TE, Dai Y, Ayares DL. Production of alpha 1,3-galactosyltransferase-deficient pigs. Science. 2003:299:411-4

17. Xin J, Yang H, Fan N, Zhao B, Ouyang Z, Liu Z, Zhao Y, Li X, Song J, Yang Y, Zou Q, Yan Q, Zeng Y, Lai L. Highly efficient generation of GGTA1 biallelic knockout inbred mini-pigs with TALENs. PLoS One. 2013;8:e84250

18. Hauschild J, Petersen B, Santiago Y, Queisser AL, Carnwath JW, Lucas-Hahn A, Zhang L, Meng X, Gregory PD, Schwinzer R, Cost GJ, Niemann H. Efficient generation of a biallelic knockout in pigs using zinc-finger nucleases. Proc Natl Acad Sci U S A. 2011;108:12013-7.

19. Gao H, Zhao C, Xiang X, Li Y, Zhao Y, Li Z, Pan D, Dai Y, Hara H, Cooper DK, Cai Z, Mou L. Production of alpha1,3-galactosyltransferase and cytidine monophosphate-N-acetylneuraminic acid hydroxylase gene doubledeficient pigs by CRISPR/Cas9 and handmade cloning. J Reprod Dev. 2017; 63:17-26.
20. Petersen B, Frenzel A, Lucas-Hahn A, Herrmann D, Hassel P, Klein S, Ziegler M, Hadeler KG, Niemann H. Efficient production of biallelic GGTA1 knockout pigs by cytoplasmic microinjection of CRISPR/Cas9 into zygotes. Xenotransplantation. 2016;23:338-46.

21. Nishio K, Tanihara F, Nguyen TV, Kunihara T, Nii M, Hirata M, Takemoto T, Otoi T. Effects of voltage strength during electroporation on the development and quality of in vitro-produced porcine embryos. Reprod Domest Anim. 2018;53:313-8.

22. Brinkman EK, Chen T, Amendola M, van Steensel B. Easy quantitative assessment of genome editing by sequence trace decomposition. Nucleic Acids Res. 2014;42:e168.

23. Barman A, Deb B, Chakraborty S. A glance at genome editing with CRISPRCas9 technology. Curr Genet. 2019.

24. Kimberland ML, Hou W, Alfonso-Pecchio A, Wilson S, Rao Y, Zhang S, Lu Q. Strategies for controlling CRISPR/Cas9 off-target effects and biological variations in mammalian genome editing experiments. J Biotechnol. 2018; 284:91-101.

25. Le QA, Hirata M, Nguyen NT, Takebayashi K, Wittayarat M, Sato Y, Namula Z, Nii M, Tanihara F, Otoi T. Effects of electroporation treatment using different concentrations of Cas9 protein with gRNA targeting Myostatin (MSTN) genes on the development and gene editing of porcine zygotes. Anim Sci 1. 2020;91:e13386

26. Cho SW, Kim S, Kim Y, Kweon J, Kim HS, Bae S, Kim JS. Analysis of off-target effects of CRISPR/Cas-derived RNA-guided endonucleases and nickases. Genome Res. 2014;24:132-41.

27. Fu Y, Foden JA, Khayter C, Maeder ML, Reyon D, Joung JK, Sander JD. Highfrequency off-target mutagenesis induced by CRISPR-Cas nucleases in human cells. Nat Biotechnol. 2013;31:822-6.

28. Dong Y, Li H, Zhao L, Koopman P, Zhang F, Huang JX. Genome-Wide OffTarget Analysis in CRISPR-Cas9 Modified Mice and Their Offspring. G3 (Bethesda). 2019;9:3645-51.

29. Kang Y, Chu C, Wang F, Niu Y. CRISPR/Cas9-mediated genome editing in nonhuman primates. Dis Model Mech. 2019;12.

30. Slaymaker IM, Gao L, Zetsche B, Scott DA, Yan WX, Zhang F. Rationally engineered Cas9 nucleases with improved specificity. Science. 2016;351: 84-8.

31. Kleinstiver BP, Pattanayak V, Prew MS, Tsai SQ, Nguyen NT, Zheng Z, Joung JK. High-fidelity CRISPR-Cas9 nucleases with no detectable genome-wide off-target effects. Nature. 2016;529:490-5.

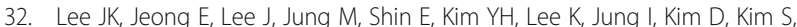
Kim JS. Directed evolution of CRISPR-Cas9 to increase its specificity. Nat Commun. 2018;9:3048

33. Tanihara F, Hirata M, Nguyen NT, Le QA, Hirano T, Takemoto T, Nakai M, Fuchimoto DI, Otoi T. Generation of a TP53-modified porcine cancer model by CRISPR/Cas9-mediated gene modification in porcine zygotes via electroporation. PLoS One. 2018;13:e0206360.

34. Tanihara F, Hirata M, Nguyen NT, Le QA, Hirano T, Takemoto T, Nakai M, Fuchimoto DI, Otoi T. Generation of PDX-1 mutant porcine blastocysts by introducing CRISPR/Cas9-system into porcine zygotes via electroporation. Anim Sci J. 2019;90:55-61.

35. Tanihara F, Hirata M, Thi Nguyen N, Anh Le Q, Hirano T, Otoi T. Generation of viable PDX1 gene-edited founder pigs as providers of nonmosaics. Mol Reprod Dev. 2020:87:471-81.

36. Wang RG, Ruan M, Zhang RJ, Chen L, Li XX, Fang B, Li C, Ren XY, Liu JY, Xiong Q, Zhang LN, Jin Y, Li L, Li R, Wang Y, Yang HY, Dai YF. Antigenicity of tissues and organs from GGTA1/CMAH/beta4GalNT2 triple gene knockout pigs. J Biomed Res. 2018.

37. Sharma A, Naziruddin B, Cui C, Martin MJ, Xu H, Wan H, Lei Y, Harrison C, Yin J, Okabe J, Mathews C, Stark A, Adams CS, Houtz J, Wiseman BS, Byrne GW, Logan JS. Pig cells that lack the gene for alpha1-3 galactosyltransferase express low levels of the gal antigen. Transplantation. 2003;75:430-6.

38. Lai $L$, Kolber-Simonds D, Park KW, Cheong HT, Greenstein JL, Im GS, Samuel M, Bonk A, Rieke A, Day BN, Murphy CN, Carter DB, Hawley RJ, Prather RS Production of alpha-1,3-galactosyltransferase knockout pigs by nuclear transfer cloning. Science. 2002;295:1089-92.

39. Huai G, Qi P, Yang H, Wang Y. Characteristics of alpha-gal epitope, anti-gal antibody, alpha1,3 galactosyltransferase and its clinical exploitation (review). Int J Mol Med. 2016:37:11-20.

40. Milland J, Christiansen D, Lazarus BD, Taylor SG, Xing PX, Sandrin MS. The molecular basis for galalpha(1,3) gal expression in animals with a deletion of the alpha1,3galactosyltransferase gene. J Immunol. 2006;176:2448-54. 
41. Butler JR, Skill NJ, Priestman DL, Platt FM, Li P, Estrada JL, Martens GR, Ladowski JM, Tector M, Tector AJ. Silencing the porcine iGb3s gene does not affect Galalpha3Gal levels or measures of anticipated pig-to-human and pig-to-primate acute rejection. Xenotransplantation. 2016;23:106-16.

42. Hai T, Teng F, Guo R, Li W, Zhou Q. One-step generation of knockout pigs by zygote injection of CRISPR/Cas system. Cell Res. 2014;24:372-5.

43. Burkard C, Lillico SG, Reid E, Jackson B, Mileham AJ, Ait-Ali T, Whitelaw CB, Archibald AL. Precision engineering for PRRSV resistance in pigs: macrophages from genome edited pigs lacking CD163 SRCR5 domain are fully resistant to both PRRSV genotypes while maintaining biological function. PLoS Pathog. 2017;13:e1006206.

44. Hirata M, Tanihara F, Wittayarat M, Hirano T, Nguyen NT, Le QA, Namula Z, Nii M, Otoi T. Genome mutation after introduction of the gene editing by electroporation of Cas9 protein (GEEP) system in matured oocytes and putative zygotes. Vitro Cell Dev Biol Anim. 2019;55:237-42.

45. Su X, Chen W, Cai Q, Liang P, Chen Y, Cong P, Huang J. Production of nonmosaic genome edited porcine embryos by injection of CRISPR/Cas9 into germinal vesicle oocytes. J Genet Genomics. 2019;46:335-42.

46. Onuma A, Fujii W, Sugiura K, Naito K. Efficient mutagenesis by CRISPR/Cas system during meiotic maturation of porcine oocytes. J Reprod Dev. 2017; 63:45-50.

47. Byrne G, Ahmad-Villiers S, Du Z, McGregor C. B4GALNT2 and xenotransplantation: a newly appreciated xenogeneic antigen. Xenotransplantation. 2018;25:e12394.

48. Nguyen DH, Tangvoranuntakul P, Varki A. Effects of natural human antibodies against a nonhuman sialic acid that metabolically incorporates into activated and malignant immune cells. J Immunol. 2005;175:228-36.

49. Hurh S, Kang B, Choi I, Cho B, Lee EM, Kim H, Kim YJ, Chung YS, Jeong JC, Hwang J, Kim JY, Lee BC, Surh CD, Yang J, Ahn C. Human antibody reactivity against xenogeneic $\mathrm{N}$-glycolylneuraminic acid and galactosealpha-1,3-galactose antigen. Xenotransplantation. 2016;23:279-92.

50. Martens GR, Reyes LM, Li P, Butler JR, Ladowski JM, Estrada JL, Sidner RA, Eckhoff DE, Tector M, Tector AJ. Humoral reactivity of renal transplantwaitlisted patients to cells from GGTA1/CMAH/B4GalNT2, and SLA class I knockout pigs. Transplantation. 2017;101:e86-92.

51. Estrada JL, Martens G, Li P, Adams A, Newell KA, Ford ML, Butler JR, Sidner $\mathrm{R}$, Tector $\mathrm{M}$, Tector J. Evaluation of human and non-human primate antibody binding to pig cells lacking GGTA1/CMAH/beta4GalNT2 genes. Xenotransplantation. 2015;22:194-202.

52. Fischer $K$, Rieblinger $B$, Hein $R$, Sfriso R, Zuber J, Fischer A, Klinger B, Liang W, Flisikowski K, Kurome M, Zakhartchenko V, Kessler B, Wolf E, Rieben R, Schwinzer R, Kind A, Schnieke A. Viable pigs after simultaneous inactivation of porcine MHC class I and three xenoreactive antigen genes GGTA1, CMAH and B4GALNT2. Xenotransplantation. 2019:e12560.

53. Zhang R, Wang Y, Chen L, Wang R, Li C, Li X, Fang B, Ren X, Ruan M, Liu J, Xiong Q, Zhang L, Jin Y, Zhang M, Liu X, Li L, Chen Q, Pan D, Li R, Cooper DKC, Yang H, Dai Y. Reducing immunoreactivity of porcine bioprosthetic heart valves by genetically-deleting three major glycan antigens, GGTA1/ beta4GalNT2/CMAH. Acta Biomater. 2018;72:196-205.

54. Liu F, Liu J, Yuan Z, Qing Y, Li H, Xu K, Zhu W, Zhao H, Jia B, Pan W, Guo J, Zhang X, Cheng W, Wang W, Zhao HY, Wei HJ. Generation of GTKO Diannan miniature pig expressing human complementary regulator proteins hCD55 and hCD59 via T2A peptide-based Bicistronic vectors and SCNT. Mol Biotechnol. 2018;60:550-62

55. Cho B, Koo OJ, Hwang Jl, Kim H, Lee EM, Hurh S, Park SJ, Ro H, Yang J, Surh CD, D'Apice AJ, Lee BC, Ahn C. Generation of soluble human tumor necrosis factor-alpha receptor 1-fC transgenic pig. Transplantation. 2011;92:139-47.

56. Kim GA, Lee EM, Cho B, Alam Z, Kim SJ, Lee S, Oh HJ, Hwang Jl, Ahn C, Lee BC. Generation by somatic cell nuclear transfer of GGTA1 knockout pigs expressing soluble human TNFRI-fc and human HO-1. Transgenic Res. 2019; 28:91-102.

57. Park SJ, Cho B, Koo OJ, Kim H, Kang JT, Hurh S, Kim SJ, Yeom HJ, Moon J, Lee EM, Choi JY, Hong JH, Jang G, Hwang Jl, Yang J, Lee BC, Ahn C. Production and characterization of soluble human TNFRI-fc and human HO1(HMOX1) transgenic pigs by using the F2A peptide. Transgenic Res. 2014; 23:407-19.

58. Zhang J, Xie C, Lu Y, Zhou M, Qu Z, Yao D, Qiu C, Xu J, Pan D, Dai Y, Hara H, Cooper DKC, Ma S, Li M, Cai Z, Mou L. Potential antigens involved in delayed Xenograft rejection in a Ggta1/Cmah Dko pig-to-monkey model. Sci Rep. 2017;7:10024.
59. Watanabe H, Sahara H, Nomura S, Tanabe T, Ekanayake-Alper DK, Boyd LK, Louras NJ, Asfour A, Danton MA, Ho SH, Arn SJ, Hawley RJ, Shimizu A, Nagayasu T, Ayares D, Lorber MI, Sykes M, Sachs DH, Yamada K. GalT-KO pig lungs are highly susceptible to acute vascular rejection in baboons, which may be mitigated by transgenic expression of hCD47 on porcine blood vessels. Xenotransplantation. 2018;25:e12391.

60. Meier RPH, Muller YD, Balaphas A, Morel P, Pascual M, Seebach JD, Buhler LH. Xenotransplantation: back to the future? Transpl Int. 2018:31:465-77.

61. Nguyen TV, Tanihara F, Do L, Sato Y, Taniguchi M, Takagi M, Van Nguyen T, Otoi T. Chlorogenic acid supplementation during in vitro maturation improves maturation, fertilization and developmental competence of porcine oocytes. Reprod Domest Anim. 2017;52:969-75.

62. Naito Y, Hino K, Bono H, Ui-Tei K. CRISPRdirect: software for designing CRIS PR/Cas guide RNA with reduced off-target sites. Bioinformatics. 2015;31: 1120-3.

63. Cradick TJ, Qiu P, Lee CM, Fine EJ, Bao G. COSMID: a web-based tool for identifying and validating CRISPR/Cas off-target sites. Mol Ther Nucleic Acids. 2014;3:e214.

64. Onishi A, Iwamoto M, Akita T, Mikawa S, Takeda K, Awata T, Hanada H, Perry AC. Pig cloning by microinjection of fetal fibroblast nuclei. Science. 2000; 289:1188-90.

65. Bennett $\mathrm{GL}$, Leymaster KA. Integration of ovulation rate, potential embryonic viability and uterine capacity into a model of litter size in swine. J Anim Sci. 1989:67:1230-41.

66. Bolet G, Botte FM, Locatelli A, Gruand J, Terqui M, Berthelot F. Components of prolificacy in hyperprolific large white sows compared with the Meishan and large white breeds. Genet Sel Evol. 1986;18:333-42.

67. Machaty Z, Day BN, Prather RS. Development of early porcine embryos in vitro and in vivo. Biol Reprod. 1998;59:451-5.

68. Pinello L, Canver MC, Hoban MD, Orkin SH, Kohn DB, Bauer DE, Yuan GC. Analyzing CRISPR genome-editing experiments with CRISPResso. Nat Biotechnol. 2016;34:695-7.

\section{Publisher's Note}

Springer Nature remains neutral with regard to jurisdictional claims in published maps and institutional affiliations.
Ready to submit your research? Choose BMC and benefit from:

- fast, convenient online submission

- thorough peer review by experienced researchers in your field

- rapid publication on acceptance

- support for research data, including large and complex data types

- gold Open Access which fosters wider collaboration and increased citations

- maximum visibility for your research: over $100 \mathrm{M}$ website views per year

At BMC, research is always in progress.

Learn more biomedcentral.com/submissions 